\title{
Investigation on the Responses of Overburden Stress and Water Pressure to Mining under the Reverse Fault
}

\author{
Chengcheng Chu \\ Department of Earth and Environment, Anhui University of Science and Technology, Huainan, Anhui 232001, China \\ Correspondence should be addressed to Chengcheng Chu; chu_cheng_cheng@126.com
}

Received 31 August 2021; Revised 29 September 2021; Accepted 6 October 2021; Published 20 October 2021

Academic Editor: Dan Ma

Copyright (C) 2021 Chengcheng Chu. This is an open access article distributed under the Creative Commons Attribution License, which permits unrestricted use, distribution, and reproduction in any medium, provided the original work is properly cited.

\begin{abstract}
This paper focuses on the responses of overburden stress and pore water pressure in confined aquifer to mining under the Ordovician limestone aquifer and the reverse fault. Taking $3_{2}$ coal seam mining in the first eastern mining area of Qianyingzi coalmine in China as engineering background, on the basis of the mining hydrogeological and engineering geological model of the study area, a numerical calculation model considering the fluid-solid interaction is established. Simulation results indicate that the variation characteristics of pore water pressure in confined aquifer and overburden stress are affected by both mining effect and geological tectonics and are closely related to the shear failure of the reverse fault plane caused by mining effect and the failure characteristics of the overburden strata in the stope. According to the variation of pore water pressure before and after the roof water inrush, the reduction range of pore water pressure can be used as one of the early warning indicators for water inrush accidents. These new understandings are of reference value to the mining water inrush under the combined action of reverse faults and confined aquifers and to the establishment of corresponding forecasting and early warning systems.
\end{abstract}

\section{Introduction}

It is a key theoretical problem of coal mine disaster control and prevention that the variation of overburden stress and pore water pressure in confined aquifer caused by coal mining. Faults not only destroy the integrity of overlying strata structure, but also affect the distribution characteristics of stress field and seepage field. According to statistics, $80 \%$ of water inrush accidents are related to faults. The systematic research and practice of coal seam mining under aquifer in China originated in the 1950s, but the research in this field mainly focuses on coal seam mining under loose aquifer [1-6]. Different from the coal mining under loose aquifer, the roof water inrush mechanism and overburden failure characteristics of coal mining under limestone (Ordovician limestone and Cambrian limestone) aquifer are often coupled with faults, which make the geological conditions of the stope more complex.

Scholars have studied the distribution rule of stress as mining under the fault and the change rule of water pressure as mining under aquifer, respectively, and obtained a lot of valuable research results [7-12]. Compared with the normal fault, the horizontal stress near the reverse fault is greater, and the influence of the horizontal stress variation in the fault zone on the stability of the fault goes up $[13,14]$. In the process of coal mining, with decreasing fault coal pillar, two sides of the fault present different characteristics of mining effect $[15,16]$. When working face advances from the footwall to the fault, the vertical stress of the coal body in front of the working face increases firstly and then decreases. Without fault, the vertical stress of the coal body in front of the working face increases gradually and tends to be stable with the working face advancing [17]. A mining-induced pore water pressure simulation experiment shows that the variation of the pore water pressure in a confined aquifer due to mining is closely related to the mining progress and periodic roof pressure [18-20]. A fluid-solid coupled numerical simulation indicates that the degree of interconnection between the bed-separated and vertical fractures, and increases in hydraulic and seepage rates in overlying strata 


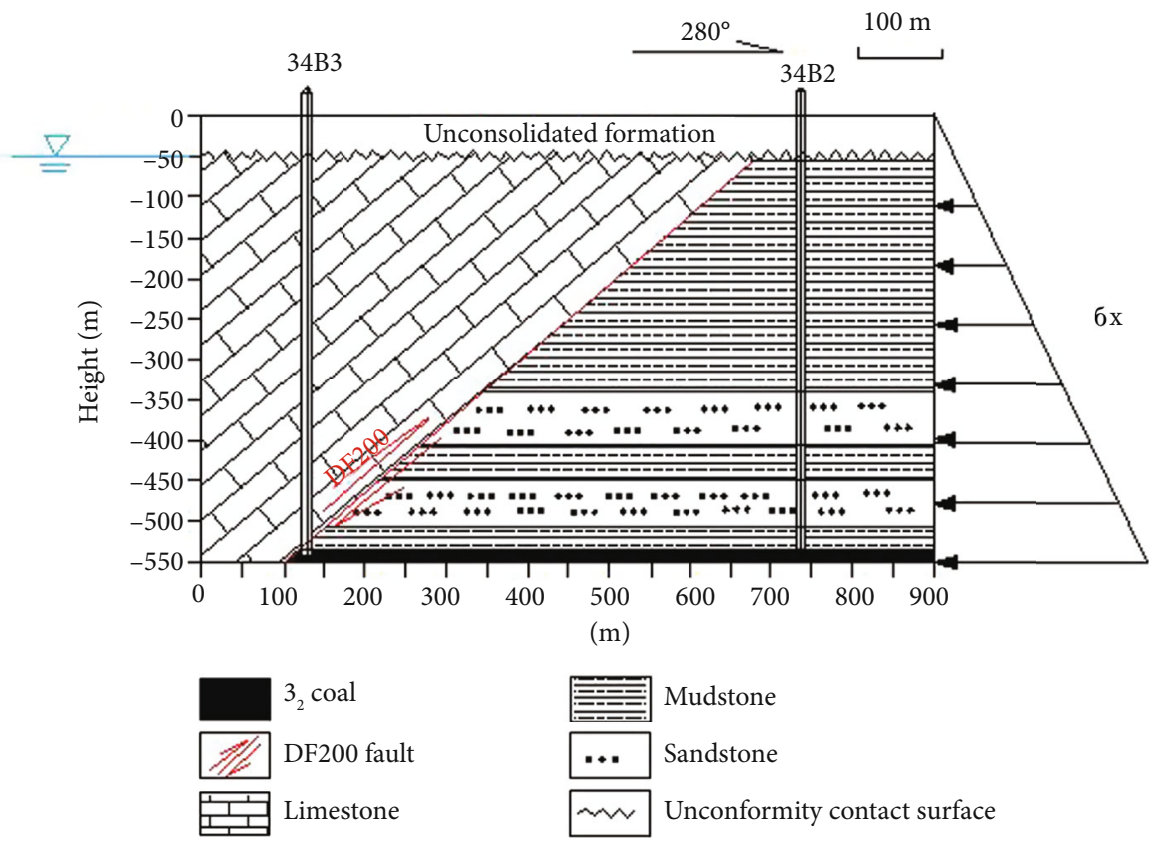

FIGURE 1: Mining hydrogeological and engineering geological model in the study area.

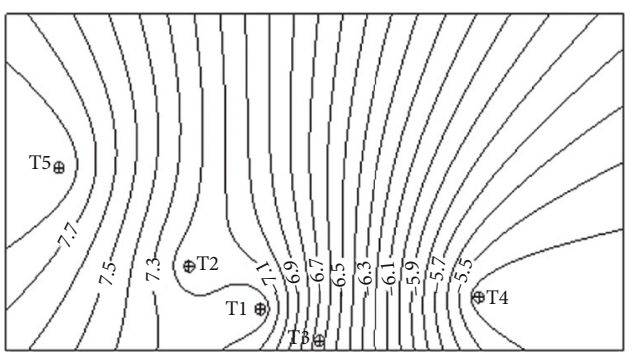

(a)

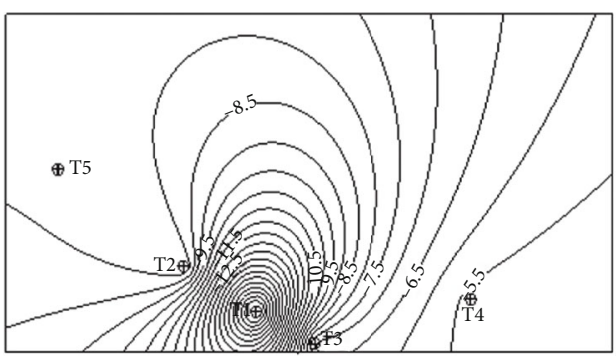

(b)

FIGURE 2: (a) Comparison of natural flow chart of limestone aquifer and (b) the flow chart of limestone aquifer after pumping 30 minutes.

are key factors in predicting potential water inrush when mining shallow coal seams under an unconsolidated, confined aquifer [21]. Nonlinear properties of rock mass can change gradually due to the erosion of flowing water during the water inrush process [6, 22-25]. These research results have laid an important theoretical foundation for the research of this paper. However, the current research pay less attention on the issue of mining under a double threat from both the fault and roof confined water, especially in the variation of overburden stress and pore water pressure under these special geological conditions.

In this paper, taking $3_{2}$ coal seam mining in the first eastern mining area of Qianyingzi coalmine in China as engineering background, the responses of overburden stress and water pressure in confined aquifer to mining under the Ordovician limestone aquifer and the reverse fault are studied with using FLAC3D software, which is aimed at revealing the roof water inrush mechanism of mining under the Ordovician limestone aquifer and the reverse fault and establishing the early warning and prediction index of roof water inrush caused by mining under the combined action of reverse faults and confined aquifers.

\section{Engineering Geological and Hydrogeological Conditions of the Research Case}

The study area is the first eastern mining area of Qianyingzi coalmine in China. Qianyingzi coalmine is located in the southwest of Suzhou City, Anhui Province, and it is a stratigraphic type of Huaibei coalfield, belonging to North China stratigraphic category. The mining depth of $3_{2}$ coal seam in the first eastern mining area of Qianyingzi coalmine is $-280 \sim-650 \mathrm{~m}$, and the average thickness of $3_{2}$ coal seam is $3.3 \mathrm{~m}$. Drilling in mining area reveals that the strata from the bottom to the top are Ordovician, Carboniferous, Permian, Neogene, and Quaternary. As shown in Figure 1, DF200 fault pushes the Ordovician limestone to the top of $3_{2}$ coal seam directly, which is a reverse fault in research area. The dip angle of DF200 fault is about 45 degrees. The roof lithology of $3_{2}$ coal seam is interbed of soft and hard strata. 


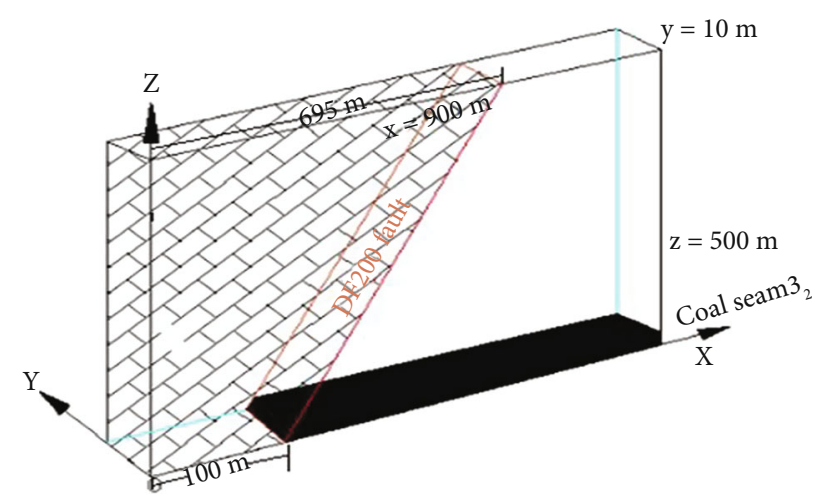

FIGURE 3: Coordinate system of numerical model.

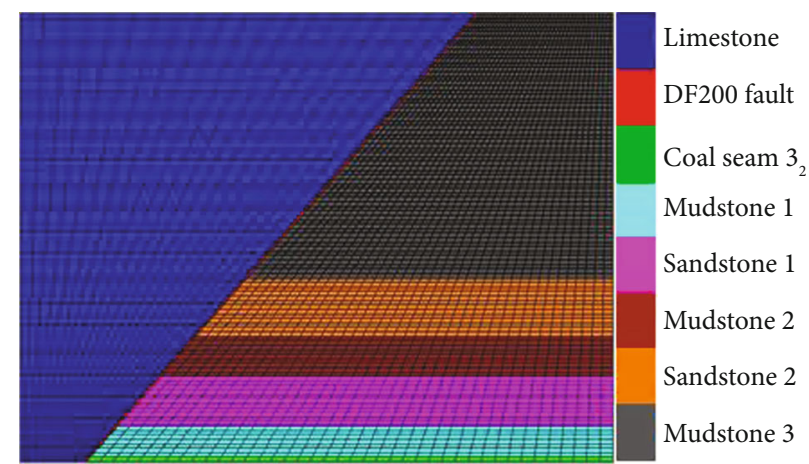

FIGURE 4: Numerical model plan.

TABLE 1: Major parameters of rocks in numerical model.

\begin{tabular}{|c|c|c|c|c|c|c|c|c|}
\hline Stratum & $\begin{array}{l}\text { Density } \\
\left(\mathrm{kg} / \mathrm{m}^{3}\right)\end{array}$ & $\begin{array}{l}\text { Bulk modulus } \\
\qquad(\mathrm{MPa})\end{array}$ & $\begin{array}{l}\text { Shear modulus } \\
\qquad(\mathrm{MPa})\end{array}$ & $\begin{array}{l}\text { Internal } \\
\text { friction } \\
\text { angle }\left(^{\circ}\right)\end{array}$ & $\begin{array}{l}\text { Cohesion } \\
\text { (MPa) }\end{array}$ & $\begin{array}{l}\text { Tension } \\
(\mathrm{MPa})\end{array}$ & $\begin{array}{l}\text { Permeability } \\
\left(\mathrm{m}^{2} / \mathrm{Pa} \cdot \mathrm{sec}\right)\end{array}$ & Porosity \\
\hline Limestone & 2090 & 22.60 & 11.10 & 42.0 & 6.72 & 1.58 & $7.0 \times 10^{-8}$ & 0.15 \\
\hline Coal seam & 1400 & 1.04 & 0.51 & 25.0 & 2.00 & 0.50 & $2.0 \times 10^{-13}$ & 0.10 \\
\hline Mudstone1 & 2020 & 8.80 & 4.30 & 25.0 & 5.00 & 0.90 & $3.0 \times 10^{-10}$ & 0.25 \\
\hline Sandstone1 & 2436 & 16.50 & 10.00 & 31.4 & 6.12 & 1.90 & $7.0 \times 10^{-10}$ & 0.22 \\
\hline Mudstone2 & 2364 & 9.00 & 5.00 & 33.1 & 2.75 & 1.30 & $3.0 \times 10^{-10}$ & 0.25 \\
\hline Sandstone2 & 2621 & 16.80 & 10.00 & 33.6 & 7.60 & 1.76 & $7.0 \times 10^{-10}$ & 0.19 \\
\hline Mudstone3 & 2537 & 8.00 & 7.00 & 34.8 & 4.42 & 1.77 & $3.0 \times 10^{-10}$ & 0.24 \\
\hline
\end{tabular}

Through the group hole unsteady flow pumping test of boreholes T1, T2, T3, T4, and T5 in the Ordovician limestone aquifer, the natural water level of each borehole and the water level change data after pumping are obtained. The flow field evolution is plotted, as shown in Figure 2. According to the calculation of water inflow and drawdown of $\mathrm{T} 1 \mathrm{hole}$, the permeability coefficient $K=2.42 \mathrm{~m} / \mathrm{d}$, and the unit water inflow $q=0.53 \mathrm{~L} /(\mathrm{s} \cdot \mathrm{m})$. The results of pumping experiments in the Ordovician limestone aquifer show that the aquifer has a hydraulic connection with the sur- rounding aquifer and is a medium water-rich aquifer. Therefore, $3_{2}$ coal seam mining is threatened by both DF200 fault and Ordovician limestone aquifer.

\section{Fluid-Solid Coupling Numerical Model}

Based on the engineering geological and hydrogeological conditions of the study area, the fluid-solid coupling numerical model is established. The coordinate system is shown in Figure 3, and the model size is $900 \mathrm{~m} \times 10 \mathrm{~m} \times 500 \mathrm{~m}$. In the 


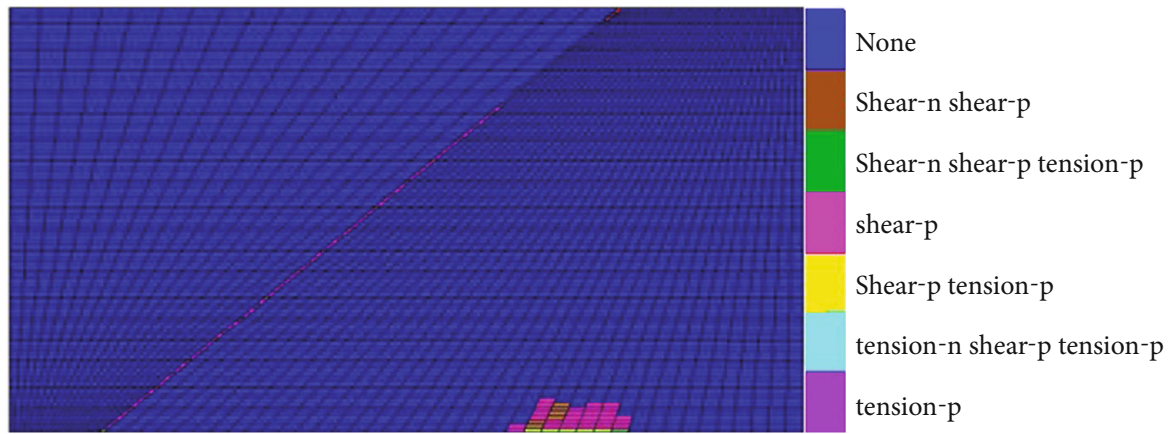

(a) Mining 3 steps

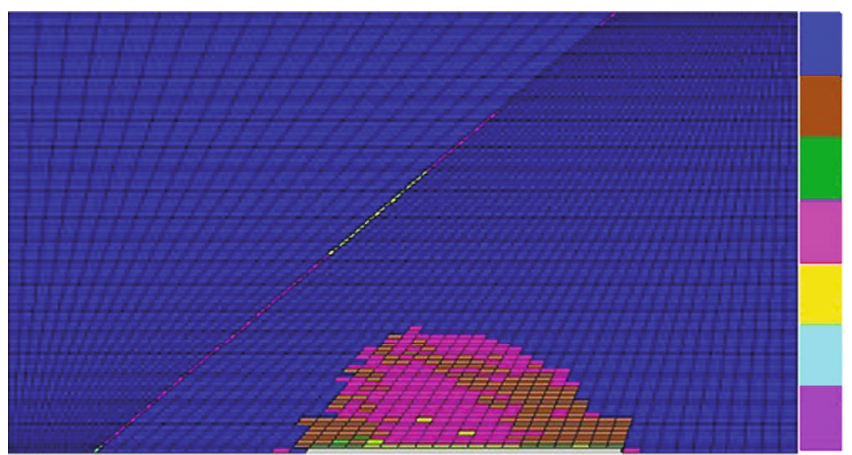

None

Shear-n shear-p

Shear-n shear-p tension- $\mathrm{p}$

shear-p

Shear-p tension-p

tension-n shear- $\mathrm{p}$ tension- $\mathrm{p}$

(b) Mining 9 steps

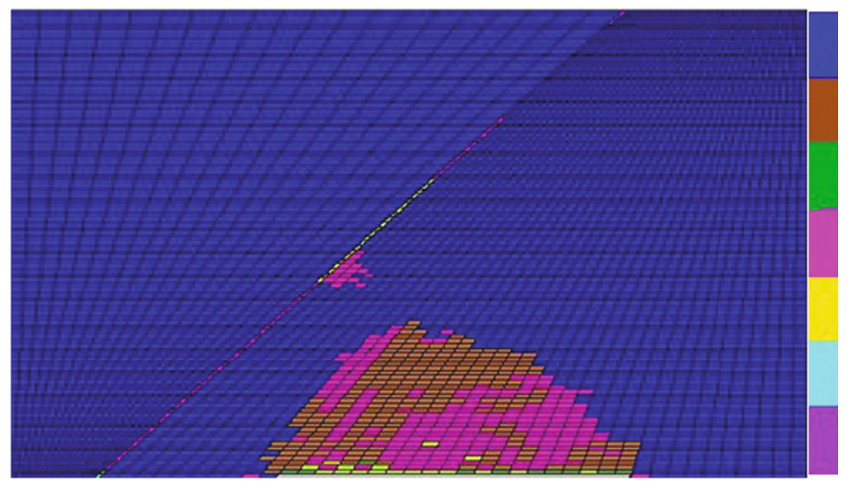

None

Shear-n shear-p

Shear-n shear-p tension- $\mathrm{p}$

shear-p

Shear-p tension-p

tension- $n$ shear- $p$ tension $-p$

tension-p

(c) Mining 10 steps

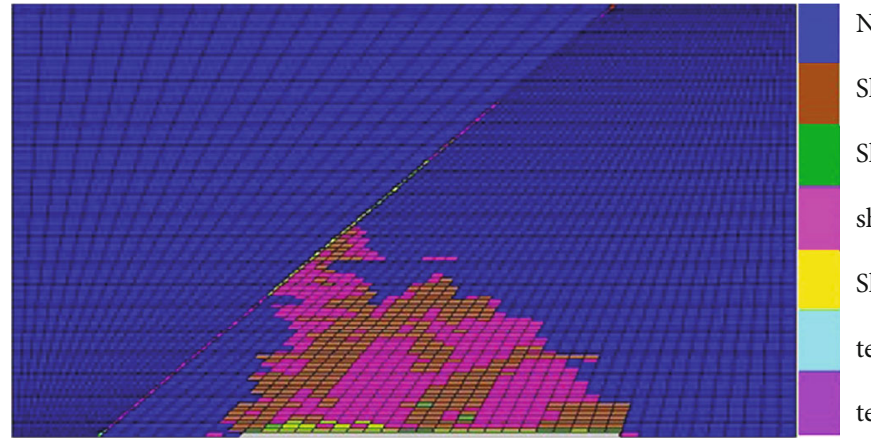

None

Shear-n shear-p

Shear-n shear-p tension-p

shear-p

Shear-p tension-p

tension-n shear-p tension-p

(d) Mining 11 steps

tension-p

Figure 5: Plastic zone development regularity in mining area. 


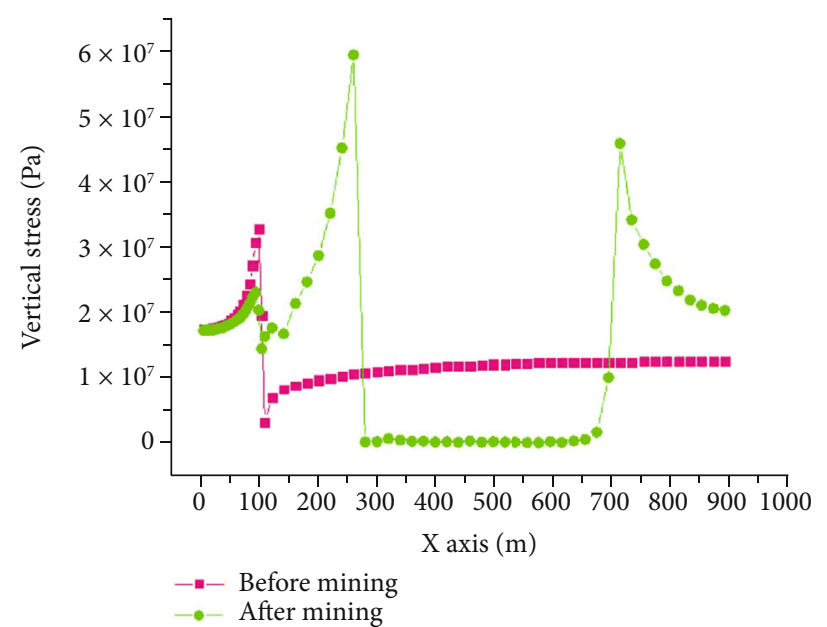

(a) $Z=7.5 \mathrm{~m}\left(X_{\mathrm{DF} 200}=109 \mathrm{~m}\right)$

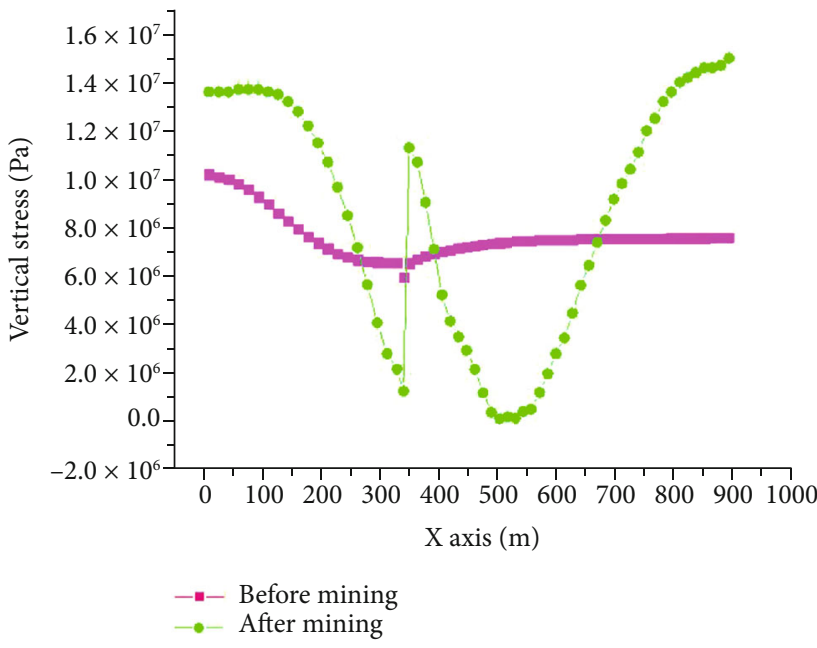

(c) $Z=200 \mathrm{~m}\left(X_{\mathrm{DF} 200}=338 \mathrm{~m}\right)$

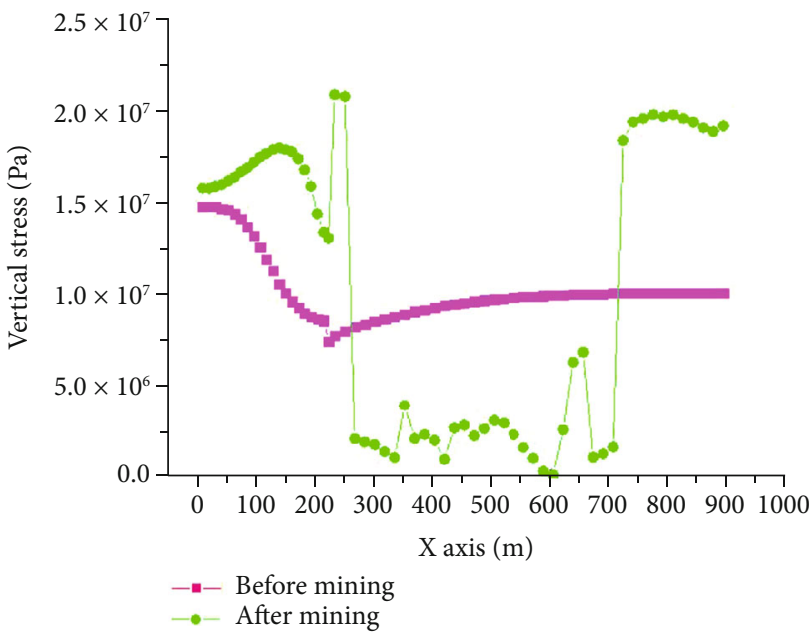

(b) $Z=100 \mathrm{~m}\left(X_{\mathrm{DF} 200}=219 \mathrm{~m}\right)$

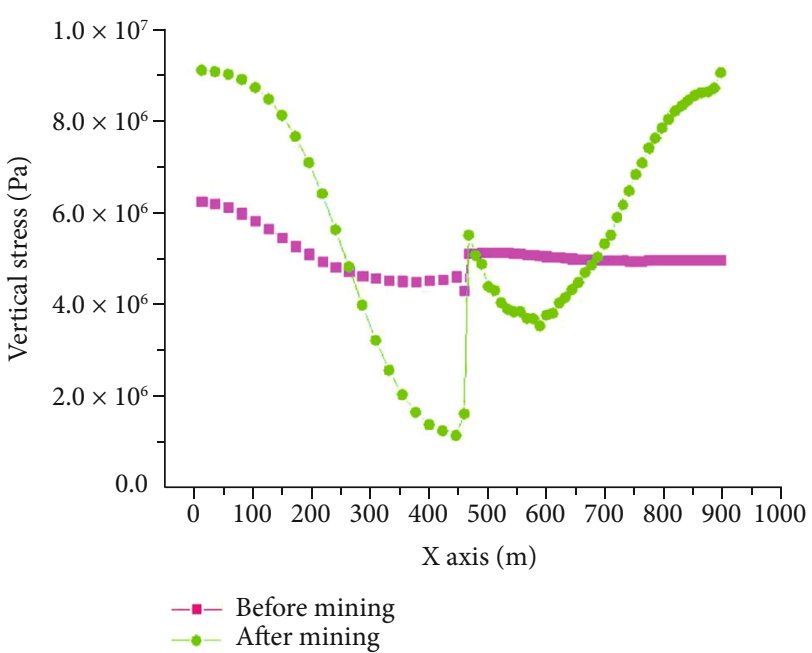

(d) $Z=300 \mathrm{~m}\left(X_{\mathrm{DF} 200}=458 \mathrm{~m}\right)$

FIGURE 6: Distribution characteristics of vertical stress.

numerical model, the gravity stress of the Quaternary loose layer is loaded by applying uniform load above the model. The compensation load is $0.5 \mathrm{MPa}$. The calculation formula is as follows:

$$
\sigma=\gamma \mathrm{z}=10 \mathrm{kN} / \mathrm{m}^{3} \times 50 \mathrm{~m}=0.5 \mathrm{MPa}
$$

where $\sigma$ is compressive stress, $\mathrm{MPa}, \gamma$ is unit weight, $\mathrm{KN} / \mathrm{m}^{3}$, and $z$ is Quaternary thickness, $\mathrm{m}$.

The Mohr-Coulomb yield criterion is adopted in the numerical simulation. The front and back boundary, the left and right boundary, and the bottom boundary of the model are fixed, and the upper boundary is free. The boundary around the model is regarded as impervious boundary, and the excavated surrounding rock boundary is free pervious boundary. For most hard rock masses, the lateral pressure coefficient $(\lambda)$ is between 0.25 and 0.43 , so the horizontal stress is about one-third to one-fifth of the vertical stress. However, the existence of faults will interfere with the regional stress field, resulting in great differences between the local stress field and the regional stress field, and the lateral pressure coefficient of the local stress field around the reverse fault is greater than 1 . Combined with the regional geological data, the lateral pressure coefficient in the numerical model is 1.65. According to the field pumping test data, the water pressure at the bottom interface of the Ordovician limestone aquifer is $6.5 \mathrm{MPa}$, and the pore water pressure before excavation is hydrostatic pressure. Moreover, the fault is generally weak in water yield and poor in water conductivity. The plane diagram of the numerical model is shown in Figure 4. The rock parameters in the numerical model are based on the physical and mechanical properties of the drilled rock, as shown in Table 1.

Considering the boundary effect, the cutting hole is $200 \mathrm{~m}$ away from the right boundary of the model. In the numerical model, coal seam thickness is $5 \mathrm{~m}$, the mining length of each step is $40 \mathrm{~m}$, and the mining plan is a full mining height. The numerical model stops mining at the eleventh step, when the roof water-conducting fracture zone 


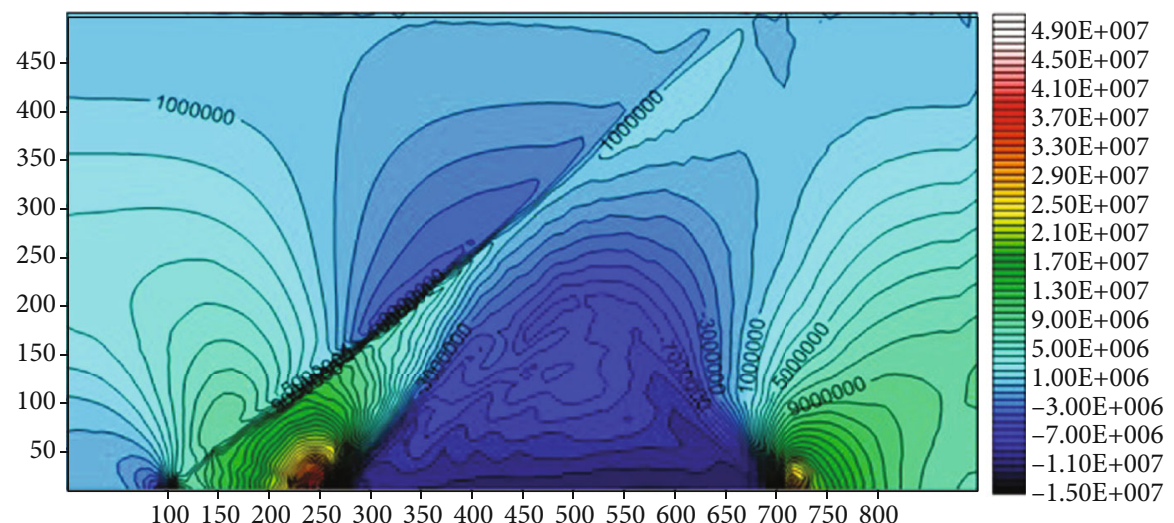

(a) Contour map of vertical stress variation after full mining (unit: Pa)

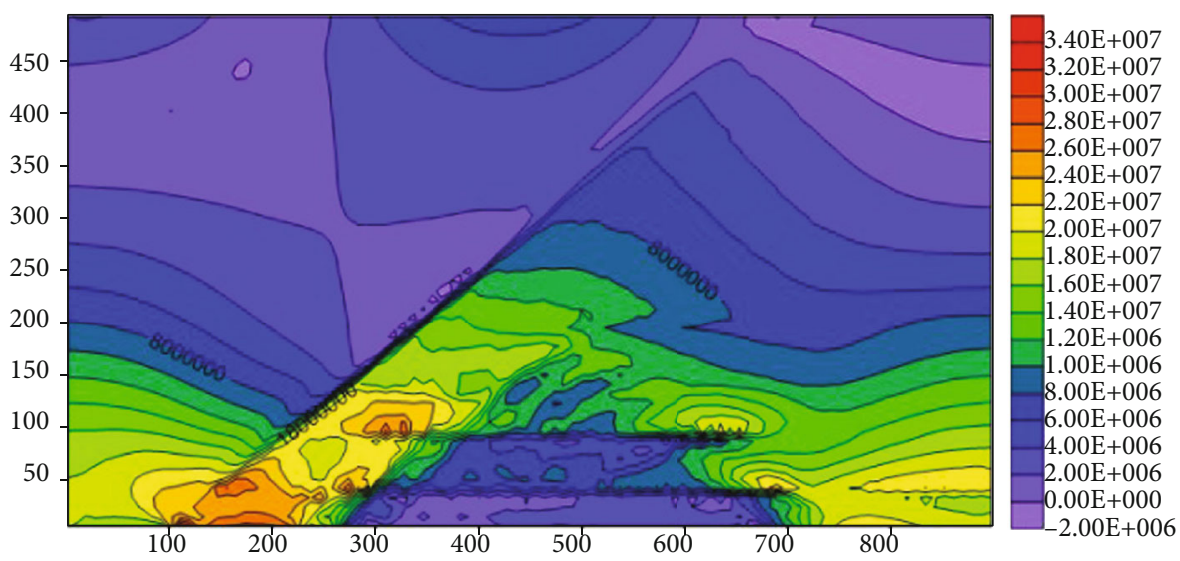

(b) Contour map of horizontal stress variation after full mining (unit: $\mathrm{Pa}$ )

FIgURE 7: Contour map of stress variation after full mining (unit: $\mathrm{Pa}$ ).

communicates with confined aquifer, and water inrush accident occurs. At this moment, the horizontal distance of the goaf is $440 \mathrm{~m}$, and the mining range is $x=260 \sim 700 \mathrm{~m}$. The horizontal range of the Ordovician limestone aquifer is $0 \sim 100 \mathrm{~m}$ at the bottom of the model and $0 \sim 695 \mathrm{~m}$ at the top of the model. In the process of the numerical calculation, the model will calculate the balance of stress field and seepage field at each mining step until water inrush occurs.

\section{Analysis of Simulation Results}

4.1. Development Characteristics of Plastic Zone. After model mining, the rock stratum above the goaf is subject to tensile failure and shear failure, and the plastic zone gradually develops upward with the increase of mining distance, as shown in Figure 5. In the mining process, after the tenth mining step, shear failure occurs near the fault zone with a horizontal height of 200 235 m in the footwall of DF200 fault. Compared with the rock height in the numerical model, this level is near the soft hard rock contact surface of mudstone 3 and sandstone 2 . At this time, the plastic zone near the fault zone is not connected with the fracture zone above the goaf. After the eleventh mining step, the plastic zone further develops and the two parts of fractures are connected. Therefore, the roof water inrush accident occurs at the eleventh mining step.
According to the drilling data of the trial mining working face in the first eastern mining area, when the working face is pushed $120 \mathrm{~m}$, the measured height of water flowing fractured zone is $42.50 \mathrm{~m}$. As shown in Figure 5(a), at the third step of mining, the scope of goaf is $120 \mathrm{~m}$, and the maximum height of plastic zone is $45 \mathrm{~m}$. Therefore, the development height of plastic zone in the stope obtained by numerical simulation is close to the actual development height.

4.2. Distribution Characteristics of Overburden Stress after Full Mining. The abscissa of the DF200 fault is recorded as $X_{\mathrm{DF} 200} . X_{\mathrm{DF} 200}$ varies at different horizontal heights. According to model coordinate system (Figure 2 ) and goaf range, if $X_{\mathrm{DF} 200}<260 \mathrm{~m}$, it indicates that the fault is located in front of the goaf. If $260 \mathrm{~m}<X_{\mathrm{DF} 200}<695 \mathrm{~m}$, the fault lies above the goaf. As shown in Figure 6, distribution characteristics of vertical stress in mining area can be summarized as follows.

(1) After the model is fully mined, when the fault lies in front of the goaf, there are two stress concentration points in front of the goaf, which are located at fault position and stopping mining position, respectively, as shown in Figures 6(a) and 6(b). In this case, the vertical stress distribution of overlying rock over 


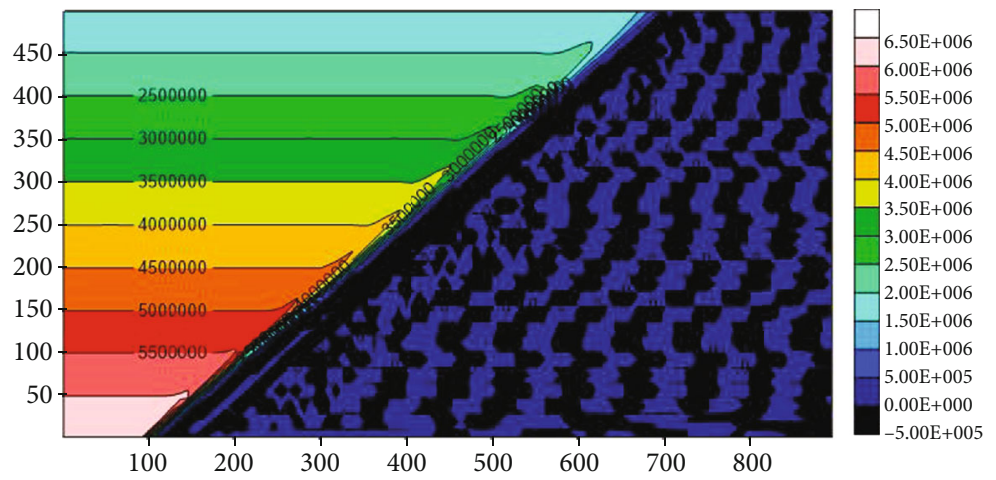

(a) Before mining

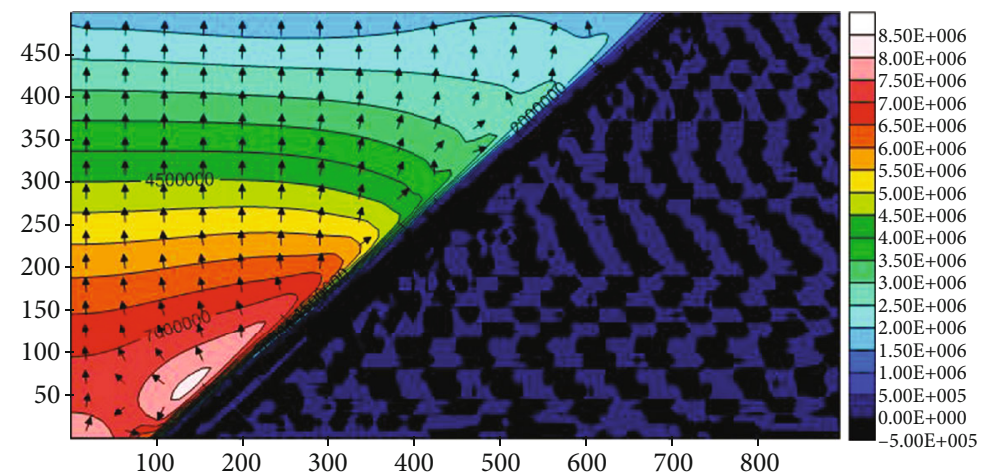

(b) Mining 6 steps

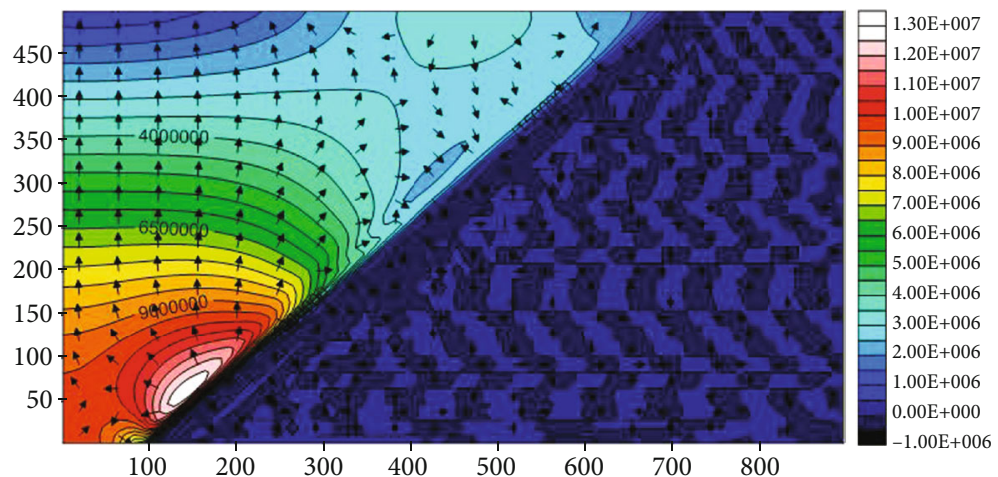

(c) Mining 9 steps

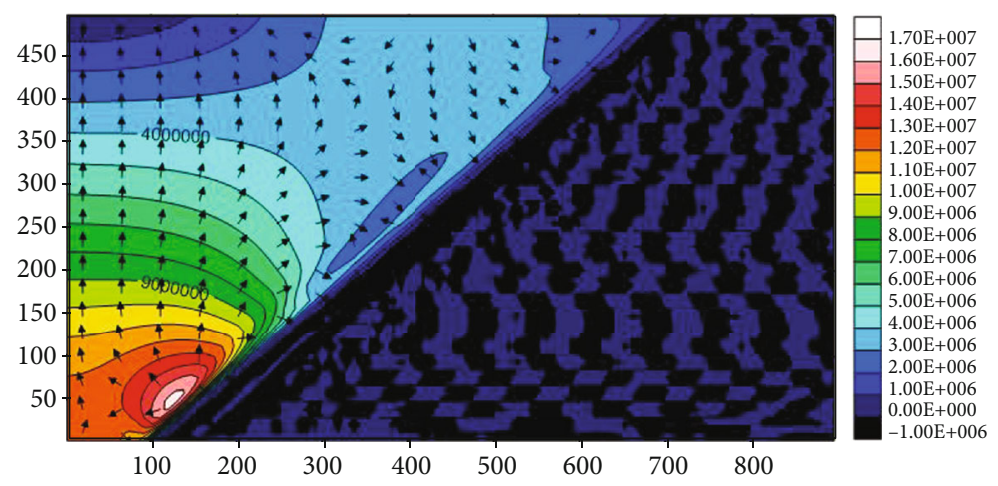

(d) Mining 11 steps

FigURE 8: Variations of confined aquifer pore water pressure with mining distances (unit: Pa). 


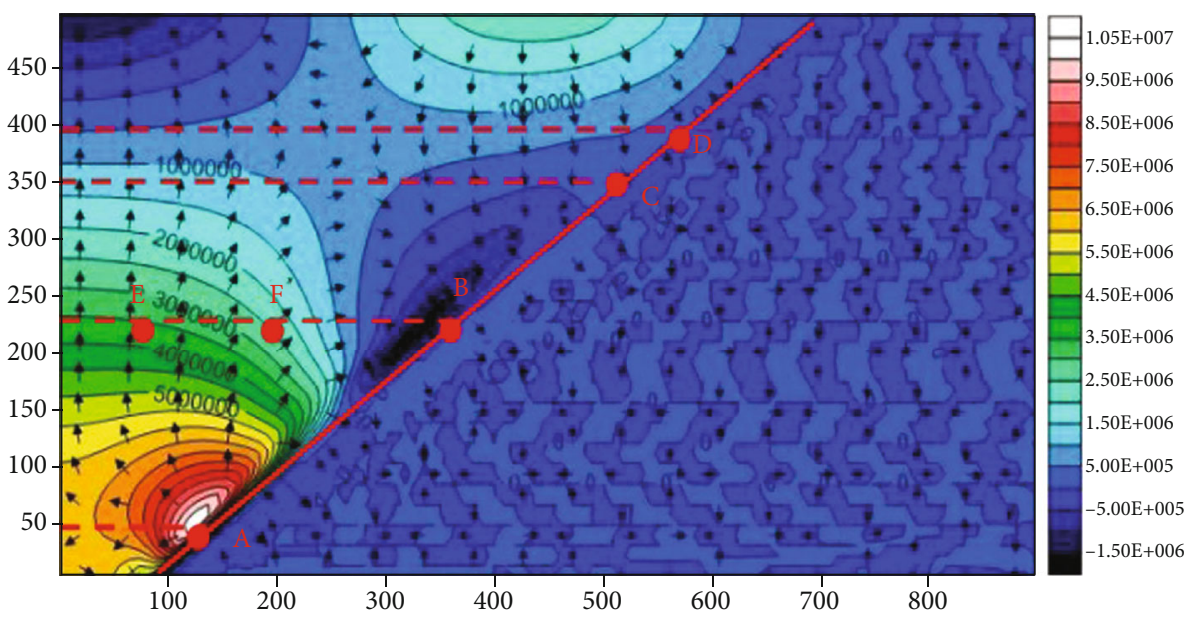

Figure 9: Contour of pore water pressure variation after full mining (unit: $\mathrm{Pa}$ ).

TABLE 2: Coordinates of pore water pressure monitoring points.

\begin{tabular}{lcccc}
\hline $\begin{array}{l}\text { Pore water pressure } \\
\text { monitoring point }\end{array}$ & $x$ coordinate $(\mathrm{m})$ & $y$ coordinate $(\mathrm{m})$ & $z$ coordinate $(\mathrm{m})$ & $\begin{array}{c}x \text { coordinate of the fault } \\
\text { at this level }(\mathrm{m})\end{array}$ \\
\hline A & 156 & 5 & 48 & 157.20 \\
B & 364 & 5 & 223 & 365.76 \\
C & 516 & 5 & 350 & 517.11 \\
D & 575 & 5 & 400 & 576.70 \\
E & 50 & 5 & 223 & 365.76 \\
F & 200 & 5 & 223 & 365.76 \\
\hline
\end{tabular}

the goaf is near to U-shape. While the fault lies above the goaf, the stress concentration is only at the fault, and the vertical stress distribution of overlying rock at this horizontal height is similar to W-shape, as shown in Figures 6(c) and 6(d)

(2) For the overburden rock strata far from the coal seam, taking the horizontal height of $z=100 \mathrm{~m}, z=$ $200 \mathrm{~m}$, and $z=300 \mathrm{~m}$ as examples, the vertical stress value of the lower wall of the fault is obviously larger than that of the upper wall of the fault. This is because the fault has a barrier effect on stress transfer, which is consistent with previous research results. However, for the strata near the coal seam, taking the horizontal height of $z=7.5 \mathrm{~m}$ as an example, the vertical stress value of the upper wall of the fault is larger than that of the lower wall of the fault. This is mainly affected by the water pressure of the confined aquifer

Different from the decrease of vertical stress above the goaf after model mining, the horizontal stress of the stope increased. It can be seen from Figure 7 that the variation of horizontal stress above the goaf gradually decreases with the decrease of rock stratum buried depth. This shows that with the increase of the vertical distance between rock stratum and coal seam, the influence of mining effect on the variation of horizontal stress decreases gradually. When the vertical distance between rock stratum and coal seam is far, the distribution characteristics of horizontal stress are mainly affected by geological structure. Based on the variation characteristics of vertical stress and horizontal stress in the stope, it can be seen that the variation of vertical stress and horizontal stress from the front of the goaf to lower wall of DF200 fault is significantly greater than that of the upper wall of the fault, indicating that the fault plays a barrier role in the transmission of stress.

4.3. Variations of Pore Water Pressure in Confined Aquifer. As shown in Figure 8, the confined aquifer water pressure maintains the layered distribution characteristics in the early stage of mining and increases gradually with the advancing of working face. After the sixth mining step, a high water pressure area forms at the height range of $25 \sim 125 \mathrm{~m}$ near the fault zone in confined aquifer. Compared with 5 6.5 MPa before model mining, the pore water pressure in this area increases to $8 \sim 9 \mathrm{MPa}$ after the sixth step of mining and even 10 18 MPa after the eleventh step. After the ninth mining step, a low water pressure zone forms in confined aquifer at the height range of 275 325 m near the fault zone. The pore water pressure in the area is $3 \sim 4 \mathrm{MPa}$ before mining, which decreases to $2 \sim 2.5 \mathrm{MPa}$ after the ninth step of mining. With the advancing of working face, the scope of low water pressure area is further expanded.

As shown in Figure 8, after full mining, the range of low water pressure area is extended to $160 \sim 340 \mathrm{~m}$, and the variation of water pressure is $0.5 \sim 1.5 \mathrm{MPa}$. In this area, the range 


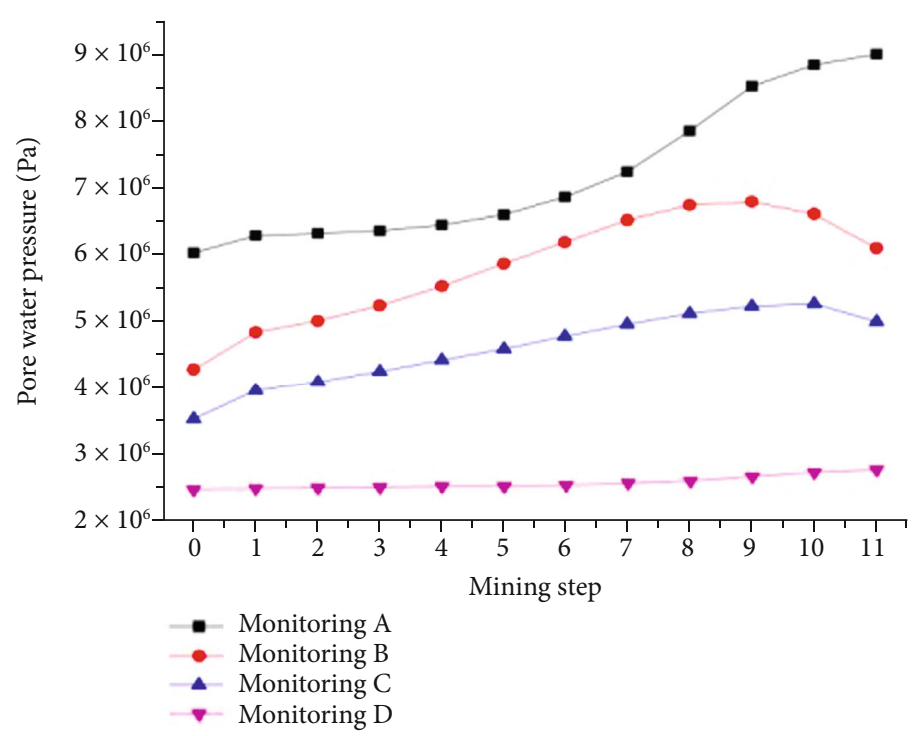

(a)

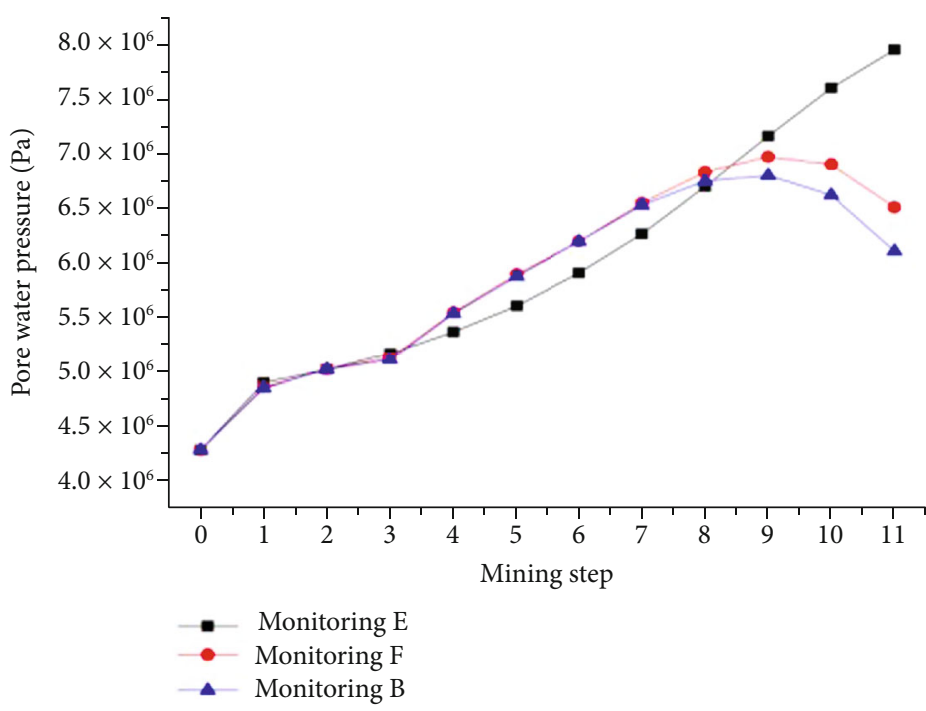

(b)

FIGURE 10: Variations of pore water pressure at monitoring points with mining steps.

of $165 \sim 240 \mathrm{~m}$ is the core low water pressure area, and the reduction of water pressure in this area is $1 \sim 1.5 \mathrm{Mpa}$. In the process of model mining, six pore water pressure monitoring points are set. Their positions and coordinates are shown in Figure 9 and Table 2, respectively. Among them, point A, point $\mathrm{B}$, point $\mathrm{C}$, and point $\mathrm{D}$ are pore water pressure monitoring points at different horizontal heights near the fault zone, and point $\mathrm{B}$, point $\mathrm{E}$, and point $\mathrm{F}$ are three pore water pressure monitoring points with different horizontal distance from the fault at the same horizontal height. As shown in Figure 10, the variation laws of pore water pressure at monitoring points with mining steps can be summarized as follows.

(1) The pore water pressure of the monitoring point at the bottom of the confined aquifer (point A) increases obviously with the increase of mining distance. The pore water pressure of the upper monitoring point of the confined aquifer (point D) has no significant change in the process of model mining. The pore water pressure of the monitoring point in the water pressure core reduction area in the confined aquifer (point B) begins to decrease after the plastic zone is generated near the fault zone. When the water inrush accident occurs, the pore water pressure of point $B$ further decreases and the reduction range is greater than that before the water inrush. The pore water pressure of point $\mathrm{C}$, which is in the water pressure reduction area but outside the core reduction area, continues to increase when plastic failure occurs near the fault and decrease at the moment of water inrush

(2) Taking the $223 \mathrm{~m}$ horizontal height as an example, the pore water pressure of point $\mathrm{E}$ continues to increase with the increase of mining distance due to far from the fault, and the pore water pressure of 
point $\mathrm{B}$ and point $\mathrm{F}$ begins to decrease after the plastic failure of the fault due to close to the fault. It indicates that near the shear failure area of the fault caused by mining effect, the closer to the fault, the greater the decrease of pore water pressure at the same horizontal height

4.4. Effect of Overburden Failure Characteristics on Pore Water Pressure Distribution. According to the development characteristics of the plastic zone in the stope and the variation law of overburden stress and pore water pressure in confined aquifer, it can be seen that the essence of roof water inrush caused by coal mining in the study area is in the footwall of the reverse fault, and the interface of hard rock and soft rock near the fault zone is fractured and has low strength, which is conducive to the development and expansion of cracks, and is vulnerable to shear failure. When the plastic zone near the fault zone is connected with the water conducting fracture zone of the coal seam roof, the roof water inrush accident occurs.

Mining in the working face causes shear failure along the reverse fault plane in the range of about $90 \mathrm{~m}$. In the fault shear failure area, the permeability increases, resulting in the formation of a pressure reduction area in the confined aquifer. In the early stage of the formation of the water pressure reduction zone, the plastic zone near the fault zone is not connected with the water conducting fracture zone of the coal seam roof, and the roof water inrush has not yet occurred. At this moment, the scope of the water pressure reduction zone is small. With the advancing of the working face, the plastic zone near the fault zone develops continuously, and the scope of the water pressure reduction area expands. At the moment of water inrush, the pore water pressure value in the water pressure reduction area further decreases, and the reduction range is larger than that before water inrush. The core area of water pressure reduction is formed in a certain area close to the fault, and the drop of water pressure is large in this area. Therefore, the reduction range of pore water pressure can be used as an early warning index for water inrush accidents.

\section{Conclusions}

Based on the analysis of engineering geological and hydrogeological conditions, the mining hydrogeological and engineering geological model of the study area is established firstly. Then, a numerical model considering the coupling effect of seepage field and stress field is established by using the FLAC3D software. Numerical simulation shows that the variation characteristics of pore water pressure in confined aquifer and overburden stress are affected by both mining effect and geological tectonics and are closely related to the shear failure of the reverse fault plane caused by mining effect and the failure characteristics of the overburden strata in the stope.

Due to the blocking effect of the fault, the stress variation of the lower wall of the fault is obviously greater than that of the upper wall of the fault near the fault zone. With the decrease of burial depth, the variation of the stress and pore water pressure in confined aquifer decreases gradually, which indicates that with the increase of vertical distance between rock and coal seam, the influence of mining effect on overburden stress and pore water pressure decreases gradually.

The pore water pressure decreases near the fault shear fracture zone and forms a water pressure reduction zone in confined aquifer. With the working face advancing, the plastic zone continues to develop, and the range of the water pressure reduction zone expands until roof water inrush. At the instant of water inrush, the decrease of pore water pressure is further increased. Therefore, the reduction range of pore water pressure can be used as one of the early warning indicators for water inrush accidents. These new understandings are of reference value to the mining water inrush under the combined action of reverse faults and confined aquifers and to the establishment of corresponding forecasting and early warning systems.

\section{Data Availability}

The data supporting the findings of this study are available within the article and are available from the corresponding author on request.

\section{Conflicts of Interest}

The author declares that there is no conflict of interest regarding the publication of this paper.

\section{Acknowledgments}

This work was supported by the Natural Science Foundation of Anhui Education Department of China under Grant No. KJ2018A0100 and the Natural Science Foundation of Anhui Science and Technology Department of China under Grant No. 1908085QE248.

\section{References}

[1] X. Z. Wang, Study on Occurrence Condition and Prevention of Support Crushing and Water Inrush Disaster during Mining under Unconsolidated Confined Aquifer, China University of Mining and Technology, Xuzhou, 2012.

[2] W. P. Shi, Research on Laws of Surface Movement under Thick Loose Layer Based on Overlying Strata Movement during Coal Mining, Shandong University of Science and Technology, Qingdao, 2019.

[3] L. W. Chen, H. R. Gui, and Y. F. Li, "UDEC simulation of the water-pouring probability in exploiting waterproof coal pillars under the conditions of thick loose bed and ultrathin overlying strata," Hydrogeology and Engineering Geology, vol. 1, pp. 5356, 2007.

[4] D. Hou, D. Li, G. Xu, and Y. Zhang, "Impact of mining thickness on dynamic subsidence characteristics in condition of mining under thick unconsolidated layers," International Journal of Coal Science and Technology, vol. 44, no. 12, pp. 191-196, 2016.

[5] C. C. He, W. Y. Lu, W. H. Zha, and F. Wang, "A geomechanical method for predicting the height of a water-flowing 
fractured zone in a layered overburden of longwall coal mining," International Journal of Rock Mechanics and Mining Sciences, vol. 143, p. 104798, 2021.

[6] D. Ma, H. Y. Duan, X. B. Li, Z. H. Li, Z. L. Zhou, and T. B. Li, "Effects of seepage-induced erosion on nonlinear hydraulic properties of broken red sandstones," Tunnelling and Underground Space Technology, vol. 91, p. 102993, 2019.

[7] M. Alber, R. Fritschen, M. Bischoff, and T. Meier, "Rock mechanical investigations of seismic events in a deep longwall coal mine," International Journal of Rock Mechanics and Mining Sciences, vol. 46, no. 2, pp. 408-420, 2009.

[8] G. F. Hofmann and L. J. Scheepers, "Simulating fault slip areas of mining included seismic tremors using static boundary element numerical modeling," Mining Technology, vol. 120, no. 1, pp. 53-64, 2011.

[9] Z. P. Meng, Y. F. Gao, A. H. Lu, R. Wang, X. Qiao, and C. Y. Huang, "Water inrush risk evaluation of coal mining under Quatemary alluvial water and reasonable design method of waterproof coal pillar," Journal of Mining and Safety Engineering, vol. 30, no. 1, pp. 23-29, 2013.

[10] J. L. Xu, W. B. Zhu, and X. Z. Wang, "Study on water-inrush mechanism and prevention during coal mining under unconsolidated confined aquifer," Journal of Mining and Safety Engineering, vol. 28, no. 3, pp. 333-339, 2011.

[11] X. Zhang and D. J. Sanderson, "Numerical modeling of the effects of fault slip on fluid flow around extensional faults," Journal of Structural Geology, vol. 18, no. 1, pp. 109-119, 1996.

[12] Y. X. Zhang, S. H. Tu, Q. S. Bai, and J. J. Li, "Overburden fissure evolution laws and water-controlling technologies in mining very thick coal seam under water-rich roof," International Journal of Mining Science and Technology, vol. 23, no. 5, pp. 693-700, 2012.

[13] J. Q. Jiang, Q. L. Wu, and H. Qu, "Characteristic of mining stress evolution and activation of the reverse fault below the hard-thick strata," Journal of China Coal Society, vol. 40, no. 2, pp. 267-277, 2015.

[14] J. Q. Jiang, Q. L. Wu, and H. Qu, "Evolutionary characteristics of mining stress near the hard-thick overburden normal faults," Journal of Mining and Safety Engineering, vol. 31, no. 6, pp. 881-887, 2014.

[15] J. W. Wu, H. S. Tong, S. J. Tong, and D. Q. Tang, "Study on similar material for simulation of mining effect of rock mass at fault zone. Chinese Journal of Rock Mechanics and," Engineering, vol. 26, no. supp.2, pp. 4171-4175, 2007.

[16] H. J. Zhao, F. S. Ma, G. Q. Li, D. M. Ding, and Y. D. Wen, "Fault effect due to underground excavation in hangingwalls and footwalls of fault," Chinese Journal of Geotechnical Engineering, vol. 30, no. 9, pp. 1372-1375, 2008.

[17] X. M. Yang, B. S. Zhang, and Y. P. Li, "Study of fault influence on structure and stability of mining face roof," Coal Technology, vol. 35, no. 3, pp. 103-105, 2016.

[18] W. H. Sui and Q. H. Dong, "Variation of pore water pressure and its precursor significance for quicksand disasters due to mining near unconsolidated formations," Chinese Journal of Rock Mechanics and Engineering, vol. 27, no. 9, pp. 19081916, 2008.

[19] W. H. Sui, G. T. Cai, and Q. H. Dong, "Experimental research on critical percolation gradient of quicksand across overburden fissures due to coal mining near unconsolidated soil layers," Chinese Journal of Rock Mechanics and Engineering, vol. 26, no. 10, p. 2084, 2007.
[20] Y. Hang, G. L. Zhang, and G. Y. Yang, "Numerical simulation of dewatering thick unconsolidated aquifer for safety of underground coal mining," Mining Science and Technology, vol. 19, no. 3, pp. 312-316, 2009.

[21] L. W. Chen, X. Q. Feng, W. P. Xie, W. Zeng, and Z. Y. Zheng, "Using a fluid-solid coupled numerical simulation to determine a suitable size for barrier pillars when mining shallow coal seams beneath an unconsolidated, confined aquifer," Mine Water and the Environment, vol. 36, no. 1, pp. 67-77, 2017.

[22] J. B. Ma, D. W. Yin, N. Jiang, S. Wang, and D. H. Yao, “Application of a superposition model to evaluate surface asymmetric settlement in a mining area with thick bedrock and thin loose layer," Journal of Cleaner Production, vol. 314, p. 128075, 2021.

[23] D. Ma, J. J. Wang, X. Cai et al., "Effects of height/diameter ratio on failure and damage properties of granite under coupled bending and splitting deformation," Engineering Fracture Mechanics, vol. 220, p. 106640, 2019.

[24] D. Ma, J. X. Zhang, H. Y. Duan et al., "Reutilization of gangue wastes in underground backfilling mining: overburden aquifer," Chemosphere, vol. 264, p. 128400, 2021.

[25] D. Ma, S. B. Kong, Z. H. Li, Q. Zhang, Z. H. Wang, and Z. L. Zhou, "Effect of wetting-drying cycle on hydraulic and mechanical properties of cemented paste backfill of the recycled solid wastes," Chemosphere, vol. 282, p. 131163, 2021. 